\title{
Pengaruh Program Kelas Bahasa Arab pada Lembaga CELAD terhadap Penguasaan Mufrodat (Kosa Kata) Mahasiswa
}

\author{
MAWARDI AHMAD* \\ ISMAIL AKZAM** \\ YENNI YUNITA***
}

\author{
*Fakutas Agama Islam (FAI) Universitas Islam Riau (UIR) \\ Jl. Kaharuddin Nasution No.113 Pekanbaru Riau 28284, \\ Email: mawardiahmad@fis.uir.ac.id \\ **Fakutas Agama Islam (FAI) Universitas Islam Riau (UIR) \\ Jl. Kaharuddin Nasution No.113 Pekanbaru Riau 28284 \\ Email: akzamalbakanbaru@fis.uir.ac.id \\ ***Fakutas Agama Islam (FAI) Universitas Islam Riau (UIR) \\ Jl. Kaharuddin Nasution No.113 Pekanbaru Riau 28284 \\ Email: yenniyunita@fis.uir.ac.id
}

\begin{abstract}
This study was motivated by the problem of mastering Arabic in the Faculty of Islamic studies (FAI), Islamic university of Riau (UIR). This problem focused on the students' quality and learning interest of FAI UIR on language mastery, both Arabic and English. This foreign language or second language mastery program such as Arabic or English is made in the form of language classes. Language classes are initially unattended by a special institution such as a language center now under the supervision of the FAI UIR language center, the forerunner of the UIR language center called CELAD (Center for Languages and Academic Development). Formulation The problem of this research is how the implementation of Arabic learning and the influence of the Arabic language class on the mastery of student learning in the Faculty of Islamic Studies UIR. The purpose of this study was to find out the implementation of Arabic learning and the influence of the Arabic language class on the mastery of student learning in the Faculty of Islamic studies. The type of this research is descriptive as well as qualitiative and quantitative research. The literature review used is language learning, the influence of the Arabic language class, and vocabulary mastery (al-mufradat). Then based on the results of the study using quantitative descriptive analysis, it found that the implementation of Arabic learning and the influence of the Arabic class on students' vocabulary mastery of FAI UIR can be said to be "good".
\end{abstract}

Keywords:Learning Arabic, Effect of Arabic Language Classes, Vocabulary Mastery (al-mufradat) 


\begin{abstract}
Abstrak: Penelitian ini dilatarbelakangi problem penguasaan bahasa Arab di lingkungan Fakultas Agama Islam UIR. Problem ini tampak pada kualitas dan minat belajar mahasiswa FAI UIR terhadap penguasaan bahasa baik itu bahasa Arab maupun bahasa Inggris. Program penguasaan bahasa asing atau bahasa kedua ini seperti bahasa Arab atau bahasa Inggris dibuat dalam bentuk kelas bahasa. Kelas bahasa pada awalnya tanpa pengawasan sebuah lembaga khusus semisal pusat bahasa kini sudah di bawah pengawasan pusat bahasa FAI UIR cikal bakal pusat bahasa UIR yang disebut CELAD (Center for Languages and Academic Development). Rumusan Masalah penelitian ini adalah bagaimana pelaksanaan pembelajaran bahasa Arab dan pengaruh kelas bahasa Arab terhadap penguasaan mufradat mahasiswa di Fakultas Agama Islam UIR. Tujuan penelitian ini adalah untuk mengetahui pelaksanaan pembelajaran bahasa Arab dan pengaruh kelas bahasa Arab terhadap penguasaan mufradat mahasiswa di Fakultas Agama Islam UIR.Jenis penelitian ini adalah penelitian deskriptif baik kualitatif dan kuantitatif. Tinjauan Pustaka yang digunakan adalah pembelajaran bahasa, pengaruh kelas bahasa Arab, dan penguasaan kosakata (al-mufradat). Maka berdasarkan hasil penelitian menggunakan analisis deskriptif kuantitatif diperoleh bahwa pelaksanaan pembelajaran bahasa Arab dan pengaruh kelas bahasa Arab terhadap penguasaan mufradat mahasiswa FAI UIR dapat dikatakan "baik" dapat dilihat data yang diperoleh dari 118 responden yang validdan peserta placement test dari empat prodi FAI UIR Pekanbaru.
\end{abstract}

Kata Kunci: Pembelajaran Bahasa Arab, Pengaruh Kelas Bahasa Arab, Penguasaan Kosakata (al-mufradat)

\section{PENDAHULUAN}

Pengajaran Bahasa Arab di Fakultas Agama Islam (FAI) Universitas Islam Riau (UIR) merupakan mata kuliah yang mengembangkan keterampilan berkomunikasi lisan dan tulisan untuk memahami dan membina kemampuan berbahasa Arab Fushah serta mengungkapkan informasi, pikiran, perasaan dan mengembangkan ilmu pengetahuan agama, pengetahuan umum dan sosial budaya. Pengajaran bahasa Arab ini, berfungsi sebagai bahasa agama dan ilmu pengetahuan, di samping sebagai alat komunikasi kenyataan yang dihadapi bahwa sesungguhnya kondisi pengajaran bahasa Arab di madrasah-madrasah/ sekolah-sekolah dan perguruan tinggi di Indonesia masih dihadapkan pada berbagai kendala dan tantangan. Kendala atau tantangan tersebut paling tidak dapat terlihat salah satunya dari segi edukatif. Pengajaran bahasa Arab masih relatif kurang ditopang oleh faktor-faktor pendidikan yang memadai. Faktor-faktor di sini di antaranya faktor kurikulum (termasuk di dalamnya orientasi dan tujuan, materi dan metodologi pengajaran serta sistem evaluasi), tenaga edukatif, sarana dan prasarana.

Salah satu unsur bahasa yang harus dimiliki oleh pebelajar bahasa asing termasuk bahasa Arab adalah kosakata. Perbendaharaan kosakata bahasa Arab yang memadai dapat menunjang seseorang dalam berkomunikasi dan menulis dengan bahasa tersebut. Dengan demikian, dapat dikatakan bahwa berbicara dan menulis yang merupakan kemahiran berbahasa tidak dapat tidak, harus didukung oleh pengetahuan dan penguasaan kosakata yang kaya, produktif dan aktual.

Melihat penguasaan mufradat bahasa Arab kebanyakan mahasiswa yang ada di FAI UIR masih sangat kurang, yang diketahui dari hasil 
placement test dan penggunaan kosa kata ketika mereka berbahasa Arab di kelas, oleh karena itu perlu diadakannya kelas tambahan diluar mata kuliah, maka dibentuklah lembaga CELAD (Center for Language and Development) sebagai pusat bahasa Arab dan Bahasa Inggris. Sedangkan penelitian ini lebih fokus terhadap penguasaan mufradhat (kosa kata) bahasa Arab mahasiswa FAI UIR yang mengikuti program ini.

Sehubungan dengan permasalahan tersebut di atas dalam penulisan penelitian ini penulis ingin mengkaji lebih lanjut bagaimana pengaruh kelas bahasa Arab terhadap penguasaan mufradat mahasiswa di Fakultas Agama Islam UIR. Dengan berfokus pada judul: "Pengaruh Kelas bahasa Arab terhadap Penguasaan Mufradat Mahasiswa Fakultas Agama Islam Universitas Islam Riau".

Agar penelitian ini lebih terarah dan tidak menyimpang dari topik yang dipersoalkan, maka penulis membatasi penelitian ini pada pengaruh kelas bahasa Arab terhadappenguasaan mufradat. Penelitian ditujukan kepada mahasiswa Fakultas Agama Islam di 4program studi (prodi) di Universitas Islam Riau (UIR) yaitu: Prodi Pendidikan Agama Islam (PAI), Prodi Ekonomi Syariah (EKIS), Prodi Pendidikan Anak Usia Dini (PIAUD), Prodi Perbankan Syariah (PBS).

Berdasarkan latar belakang tersebut di atas, maka dapat dirumuskan masalah sebagai berikut: Bagaimana pelaksanaan pembelajaran bahasa Arab di Fakultas Agama Islam UIR; danBagaimana pengaruh kelas bahasa Arab terhadap penguasaan mufradat mahasiswa di Fakultas Agama Islam UIR?

Dalam menjawab permasalahan tersebut di atas, tujuan penelitian ini adalah untuk mengetahui pelaksanaan pembelajaran bahasa Arab dan pengaruh kelas bahasa Arab terhadap penguasaan mufradat mahasiswa di Fakultas Agama Islam UIR.

Adapun manfaat yang diharapkan dari penelitian ini sebagai berikut: (a) Secara Teoritis, Penelitian ini dapat dijadikan bahan informasi sebagai masukan bagi lembaga-lembaga pendidikan yang berguna meningkatkan mutu pendidikan, khususnya bagi para pendidik, agar dapat mengembangkan program pengajaran bahasa Arab dengan mengoptimalkan pembelajaran bahasa Arab sehingga lebih inovatif dan menyenangkan; dan (b) Secara Praktis, Penelitian ini dapat digunakan sebagai pedoman bagi para dosen bahasa Arab/ mata kuliah ilmu-ilmu Islam dalam menerapkan pengajaran bahasa Arab dan pembelajaran berbahasa Arab untuk meningkatkan mufradat bahasa Arab mahasiswa Fakultas Agama Islam Universitas Islam Riau.

\section{LANDASAN TEORI Peranan Bahasa}

Bahasa Arab sesungguhnya merupakan bagian tak terpisahkan dari kehidupan umat Islam. Oleh karena itu, mempelajari dan menguasai bahasa menjadi keperluan setiap muslim. Baginya, bahasa Arab perlu untuk membentuk pribadi sebagai muslim dan meningkatkan kualitas keimanan dan pemahaman terhadap ajaran agama, bahkan perlu sebagai sarana dakwah penyebaran agama Islam. Bahasa Arab perlu dipandang sebagai "bahasa agama" dan bukan sebagai bahasa budaya, etnis, kawasan, maupun negara tertentu saja. Itu ditandai dengan banyaknya tokoh dan ulama muslim yang berasal dari bukan kawasan Arab, semisal Al-Gazali, AlBiruni, Ibnu Sina, Al-Razi, Al-Kindi, 
dsb., namun menguasai bahasa Arab sebagai bagian dari studi Islam yang mereka tekuni. Selain itu, agama Islam, yang salah satu unsurnya adalah bahasa Arab, seyogyanya menjadi budaya yang dominan mewarnai kehidupan umat Islam di tingkat pribadi, keluarga, dan masyarakat. (Choiriyah: 2013)

Dalam konteks bahasa Arab, bahasa Arab adalah alat atau media komunikasi dan interaksi dalam dunia global, yang mana bahasa Arab dewasa ini merupakan salah satu bahasa dunia yang diperhitungkan. Selain itu, bahasa Arab adalah bahasa pokok ajaran agama Islam yang menjadi bahasa AlQuran dan Hadits serta bahasa khazanah keilmuan Islam yang dikarang oleh ulama-ulama terdahulu yang tinggi akan nilai ilmiahnya. Sehingga sudah menjadi seharusnya sebagai orang muslim untuk mempelajari bahasa Arab, agar dapat memahami ajaran agama Islam secara benar dan komprehensif. Karena untuk memahami ajaran Islam secara benar dan komprehensif tidak cukup hanya dengan terjemahan-terjemahan yang ada dan sangat terbatas, tapi butuh juga mengkaji dan mendalami karya ulama-ulama yang juga berbahasa Arab. Karena karya-karya mereka merupakan interpretasi isi Al-Quran dan Hadits yang perlu dipertimbangkan serta merupakan hasil eksperimen-eksperimen tentang kehidupan masa lalu. (Choiriyah: 2013).

\section{Program Pengajaran Bahasa Arab}

Menurut Choiriyah (2013) bahwa program pengajaran merupakan suatu rencana pengajaran sebagai panduan bagi guru atau pengajar dalam melaksanakan pengajaran. Agar pengajaran bisa berjalan dengan efektif dan efisien, maka perlu kiranya dibuat suatu program pengajaran. Program pengajaran yang dibuat oleh guru tidak selamanya bisa efektif dan dapat dilaksanakan dengan baik, oleh karena itulah agar program pengajaran yang telah dibuat yang memiliki kelemahan tidak terjadi lagi pada program pengajaran berikutnya, maka perlu diadakan program pengajaran yang tepat dalam pengajaran dan pembelajaran.

Program pengajaran atau progjar adalah salah satu isi dari paket instruksi, progjar dibuat dengan tujuan agar dalam proses pembelajaran terarah dan sistematis tidak menyimpang dari pokok-pokok materi yang akan disampaikan, sehingga tercapainya tujuan dari sasaran pendidikan khususnya dalam penyampaian materi.

Tujuan pengajaran bahasa Arab yang menjadi fokus penelitian adalah empat keterampilan dasar berbahasa yang mengacu kepada konsep yang dikemukakan oleh Abdul Hamid Fayid. (Choiriyah: 2013)

Setiap program pengajaran bahasa pada dasarnya menginginkan hasil yang sama, yaitu agar para pembelajar dapat membaca, berbicara, memahami dan mengerti penempatan-penempatan tata bahasa asing yang dipelajari.

Choiriyah (2013) juga mengungkapkan bahwa berbicara mengenai pelaksanaan program pengajaran, pandangan dan pemikiran seolah diarahkan kepada berlangsungnya sebuah interaksi antara guru yang mengajar dan santri yang belajar dalam sebuah lingkungan belajar yang direncanakan secara khusus untuk menuju kepada tujuan pengajaran yang telah ditentukan sebagaimana dinyatakan oleh S. Nasution bahwa terdapat lima faktor 


\section{yang menjadi pendorong bagi keberhasilan pengajaran. Yaitu kepribadian guru, materi pengajaran, kemampuan pebelajar menyerap pelajaran, kesungguhan dan alokasi waktu yang disediakan.}

Berdasarkan pernyataan ini dapat dilihat bahwa interaksi yang aktif antara dua komponen pengajaran yaitu pebelajar dan pengajar atau mahasiswa dan dosen dianggap sebagai salah satu penentu dalam keberhasilan pengajaran yang didukung oleh program pengajaran yang baik.

\section{Tujuan Pengajaran Bahasa Arab}

Merumuskan tujuan dalam bentuk pernyataan mengenai tingkah laku ataupun kondisi yang dikehendaki merupakan langkah penting dalam penetapan program pengajaran (metodologi). Sebagaimana dinyatakan oleh Henry Guntur Taringan (1993, hal. 93) setelah tujuan dan isi program bahasa ditentukan dan ditetapkan, maka keputusan-keputusan mengenai sistem pengajaran dapat dibuat secara terperinci.

Menurut Ivor k. Davis (1991, hal. 94) dalam artian yang luas tujuan belajar adalah suatu pernyataan tentang perubahan yang diharapkan. Perubahan ini, diinginkan dan dinilai oleh guru dan pelatih, diharapkan akan terjadi dalam pikiran, perbuatan dan perasaan pebelajar sebagai hasil dan pengalaman pendidikan.

Dalam konteks pengajaran bahasa Arab, tujuan pembelajaran bahasa Arab terkait dengan fungsi bahasa Arab itu sendiri. Selain berfungsi sebagai alat komunikasi, baik pada taraf nasional maupun internasional. Bahasa Arab memiliki fungsi sebagai bahasa agama, berfungsi terhadap pengembangan ilmu pengetahuan, berfungsi terhadap hubungan antar bangsa. Sebagai bahasa agama, bahasa Arab memiliki peranan yang cukup signifikan, sebagai kunci untuk menyingkap tabir ilmu pengetahuan dan sekaligus menjadi bahasa ilmiah bagi kajian keislaman. Sebagaimana dikemukakan oleh Ronald Wardaugh (1970, hal. 11) "As the language of the Qur'an, Arabic is to some extent familiar through out the muslim world, rather al latin is inthe lands of the roman church". (sebagai bahasa Alqur"an, bahasa Arab sangat dikenal dan memiliki mulai tersendiri di negara muslim, sebagaimana bahasa latin bagi wilayah-wilayah penganut gereja Roma).

Menurut Mahmud Yunus (1977, hal. 21-22) tujuan mempelajari bahasa Arab ialah: (a). Supaya paham dan mengerti apa-apa yang dibaca dalam shalat dengan pengertian yang mendalam; (b). Supaya mengerti membaca Al-Qur'an, sehingga dapat mengambil petunjuk dan pengajaran dari padanya; (c). Supaya dapat belajar ilmu agama Islam melalui buku-buku yang banyak dikarang dalam bahasa Arab seperti Ilmu Tafsir, Hadits, Fiqih, dan lain-lain; (d). Supaya pandai berbicara dan mengarang dalam bahasa Arab untuk berhubungan dengan kaum muslimin di luar negeri, karena bahasa Arab merupakan bahasa umat Islam di seluruh dunia dan salah satu bahasa internasional.

Dari kedua pernyataan di atas dapat diketahui bahwa pada dasarnya pengajaran bahasa Arab bertujuan untuk memperoleh empat keterampilan dasar berbahasa, yaitu: kemampuan untuk menyimak, kemampuan untuk berbicara, kemampuan untuk membaca dan kemampuan untuk menulis. 
Berdasarkan pemaparan mengenai tujuan pengajaran bahasa Arab yang telah dikemukakan di atas, pada umumnya pengajaran bahasa Arab dimaksudkan untuk memberikan kepada peserta didik empat keterampilan dasar dalam berbahasa yang dianggap sebagai bentuk-bentuk dasar keterampilan bahasa dalam masyarakat yaitu : kemampuan membaca, menulis, berbicara dan mendengarkan. Kemudian dari keempat keterampilan dasar bahasa ini dikembangkan dan diperdalam lagi dengan memberikan wawasan mengenai sosio kultural yang terdapat dalam bahasa Arab ataupun pendalaman mengenai cabang-cabang ilmu bahasa Arab, seperti balaghah, tarikh adab dan lainlain.

Dalam konteks pengajaran bahasa Arab di Fakultas Agama Islam UIR, tujuan pengajaran bahasa arab telah ada sejak didirikannya FAI UIR. Yaitu agar mahasiswa mampu mamahami bahasa Arab baik secara mendengar maupun tulisan dan agar mahasiswa mampu mengungkapkan pendapat-pendapat dan perasaan baik secara lisan maupun tulisan.

\section{Pembelajaran Kosakata (al- Mufradât)}

Pembelajaran kosakata (almufradât) tidak berdiri sendiri. Kosakata (al-mufradât) hendaknya tidak diajarkan sebagai mata pelajaran yang berdiri sendiri melainkan sangat terkait dengan pembelajaran muthâla'ah, istimâ', insyâ', dan muhâdatsah.

Pembatasan makna. Dalam pembelajaran kosakata hendaknya makna harus dibatasi sesuai dengan konteks kalimat saja, mengingat satu kata dapat memiliki beberapa makna.
Bagi para pemula, sebaiknya diajarkan kepada makna yang sesuai dengan konteks agar tidak memecah perhatian dan ingatan peserta didik. Sedang untuk tingkat lanjut, penjelasan makna bias dikembangkan dengan berbekal wawasan dan cakrawala berpikir yang lebih luas tentang makna kata dimaksud.

Kosakata dalam konteks. Beberapa kosakata dalam bahasa asing (Arab) tidak bisa dipahami tanpa pengetahuan tentang cara pemakaiannya dalam kalimat. Kosakata seperti ini hendaknya diajarkan dalam konteks agar tidak mengaburkan pemahaman pebelajar.

Terjemah dalam pengajaran kosakata. Pembelajaran kosakata dengan cara menerjemahkan kata ke dalam bahasa ibu adalah cara yang paling mudah, namun mengandung beberapa kelemahan. Kelemahan tersebut antara lain dapat mengurangi spontanitas pebelajar ketika menggunakannya dalam ungkapan saat berhadapan dengan benda atau objek kata, lemah daya lekatnya dalam ingatan pebelajar, dan juga tidak semua kosakata bahasa asing ada padanannya yang tepat dalam bahasa ibu. Oleh karena itu, cara penerjemahan ini direkomendasikan sebagai senjata terakhir dalam pembelajaran kosakata, digunakan untuk kata-kata abstrak atau kata-kata yang sulit diperagakan untuk mengetahui maknanya.

\section{Pembelajaran Kosakata (al- Mufradât)}

Metode pembelajaran pada hakikatnya adalah teknik-teknik dalam menyampaikan materi pelajaran kepada pelajar yang jenisnya beragam dan pemanfaatannya disesuaikan dengan kebutuhan. Begitu pula halnya dengan pembelajaran bahasa Arab 
khususnya kosakata (al-mufradât) ini menuntut adanya metode-metode dasar yang dapat diterapkan tanpa mengharuskan adanya sarana-sarana yang tidak terjangkau oleh lembagalembaga pendidikan yang mengajarkan bahasa Arab.

Dalam pembelajaran kosakata (al-mufradât) ada baiknya dimulai dengan kosakata dasar yang tidak mudah berubah, seperti halnya istilah kekerabatan, nama-nama bagian tubuh, kata ganti, kata kerja pokok serta beberapa kosakata lain yang mudah untuk dipelajari. Metode yang bisa digunakan dalam pembelajarannya antara lain yaitu metode secara langsung, metode meniru dan menghafal, metode Aural-Oral Approach, metode membaca, metode Gramatika-Translation, metode pembelajaran dengan menggunakan media kartu bergambar dan alat peraga serta pembelajaran dengan lagu atau menyanyi Arab. Teknik yang dapat dilakukan yakni dengan berbagai teknik permainan bahasa, misalnya dengan perbandingan, memperhatikan susunan huruf, penggunaan kamus dan lainnya.

Ahmad Fuad Effendy dalam Metodologi Pengajaran Bahasa (2009), menjelaskan lebih rinci tentang tahapan dan teknik-teknik pembelajaran kosakata (al-Mufradât) atau pengalaman pebelajar dalam mengenal dan memperoleh makna kata (al-mufradât), sebagai berikut:

Mendengarkan kata. Ini merupakan tahapan pertama yaitu dengan memberikan kesempatan kepada pebelajar untuk mendengarkan kata yang diucapkan guru atau media lain, baik berdiri sendiri maupun di dalam kalimat. Apabila unsur bunyi dari kata itu sudah dikuasai oleh pebelajar, maka untuk selanjutnya pebelajar akan mampu mendengarkan secara benar.

Mengucapkan kata. Dalam tahap ini, guru memberi kesempatan kepada pembelajar untuk mengucapkan kata yang telah didengarnya. Mengucapkan kata baru akan membantu pebelajar mengingat kata tersebut dalam waktu yang lebih lama.

Mendapatkan makna kata. Pada tahap ini guru hendaknya menghindari terjemahan dalam memberikan arti kata kepada pebelajar, karena bila hal itu dilakukan maka tidak akan terjadi komunikasi langsung dalam bahasa yang sedang dipelajari, sementara makna kata pun akan cepat dilupakan oleh pembelajar. Ada beberapa teknik yang bisa digunakan oleh guru untuk menghindari terjemahan dalam memperoleh arti suatu kata, yaitu dengan pemberian konteks kalimat, definisi sederhana, pemakaian gambar/foto, sinonim (murâdif), antonim (dlid), memperlihatkan benda asli atau tiruannya, peragaan gerakan tubuh, dan terjemahan sebagai alternatif terakhir bila suatu kata memang benar-benar sukar untuk dipahami oleh pebelajar.

Membaca kata. Setelah melalui tahap mendengar, mengucapkan, dan memahami makna kata-kata (kosakata) baru, guru menulisnya di papan tulis. Kemudian pebelajar diberikan kesempatan membaca kata tersebut dengan suara keras.

Menulis kata. Penguasaan kosakata pebelajar akan sangat terbantu bilamana ia diminta untuk menulis kata-kata yang baru dipelajarinya (dengar, ucap, paham, baca) mengingat karakteristik kata tersebut masih segar dalam ingatan pebelajar.

Membuat kalimat. Tahap terakhir dari kegiatan pembelajaran kosakata adalah menggunakan kata- 
kata baru itu dalam sebuah kalimat yang sempurna, baik secara lisan maupun tulisan. Guru harus kreatif dalam memberikan contoh kalimatkalimat yang bervariasi dan pebelajar diminta untuk menirukannya. Dalam menyusun kalimat-kalimat itu hendaknya digunakan kata-kata yang produktif dan aktual agar pebelajar dapat dengan memahami dan mempergunakannya sendiri.

Prosedur atau langkah-langkah pembelajaran kosakata di atas tentunya dapat dijadikan acuan para pengajar bahasa asing khususnya bahasa Arab, walaupun tidak semua kata-kata baru harus dikenalkan dengan prosedur dan langkah-langkah tersebut. Faktor alokasi waktu dalam hal ini juga harus diperhitungkan. Oleh karena itu, perlu dilakukan pemilihan kata-kata tetentu yang dianggap sukar atau kata-kata yang memang hanya dapat dipahami secara baik dan utuh maknanya bilamana dihubungkan serta disesuaikan dengan konteks wacana.

\section{METODE PENELITIAN Jenis Penelitian}

Berdasarkan pembahasan dan penjelasan di bab sebelumnya, maka jenis penelitian ini adalah penelitian deskriptif kualitatif dan kuantitatif.

Penelitian deskriptif menggambarkan perilaku, pemikiran, atau perasaan suatu kelompok atau individu. Contoh umum dari penelitian deskriptif adalah jajak pendapat, yang menggambarkan sikap suatu kelompok orang. Dalam Penelitian Deskriptif, peneliti kecil upayanya untuk menghubungkan perilaku yang diteliti dengan variabel lainnya ataupun menguji atau menjelaskan penyebab sistematisnya. Seperti namannya, Penelitian Deskriptif hanya mendeskripsikan.
Tujuan Penelitian Deskriptif adalah menggambarkan karakteristik atau perilaku suatu populasi dengan cara yang sistematis dan akurat. Biasanya, Penelitian deskriptif tidak didesain untuk menguji hipotesis, tetapi lebih pada upaya menyediakan informasi seputar karakter fisik, sosial, perilaku, ekonomi, atau psikologi dari sekelompok orang.

Jenis Penelitian deskriptif yang biasa diterapkan adalah: (1) Penelitian survey, (2) Penelitian demografis, dan (3) Penelitian epidemiologis.

Adapun kualitatif dan

kuantitatif adalah sebagai berikut: (1) Landasan berpikir dari pendekatan kuantitatif adalah filsafat positivisme yang dikembangkan pertama kali oleh Emile Durkheim. Pandangan filsafat positivisme ini menyatakan bahwa tindakan-tindakan manusia terwujud dalam gejala-gejala sosial yang disebut fakta-fakta sosial. Penggunaan data kuantitatif diperlukan dalam analisis yang dapat dipertanggungjawabkan kesahihannya demi tercapainya ketepatan pengguna model hubungan variabel bebas dan variabel tergantung; dan (2) Pendekatan kualitatif. Landasan berpikir dalam pendekatan kualitatif adalah pemikiran Max Weber yang menyatakan bahwa pokok penelitian sosiologi bukan hanya gejala-gejala sosial, tetapi maknamakna yang terdapat di balik tindakantindakan perorangan yang mendorong terwujudnya gejala-gejala sosial tersebut. Oleh karena itu, metode yang utama dalam ilmu sosial adalah Verstehen atau pemahaman (jadi bukan Eeklaren atau penjelasan).

Penelitian ini dilakukan di berbagai program studi yang di Fakultas Agama Islam (FAI) Universitas Islam Riau (UIR) di Pekanbaru, Sedangkan waktu penelitiannya pada bulan Agustus sampai dengan 
November 2018. Hal ini disebabkan pelaksanaannya disesuaikan dengan dimulainya kelas bahasa Arab FAI UIR di bawah kelembagaan pusat bahasa yaitu Centre For Languages and Academic Development (CELAD).

Dalam penelitian ini yang dijadikan populasi adalah mahasiswa dari empat program studi yang ada di FAI UIR yakni, prodi Agama Islam(PAI), prodi Ekonomi Islam(EKIS), Prodi Pendidikan Islam Anak Usia Dini(PIAUD), dan prodi Perbankan Syariah(PBSy). Program ini merupakan program tahunan selama dua semester bagi mahasiswa baru FAI UIR untuk mengikuti kelas bahasa Arab dan bahasa Inggris, yang mana setelah mengikuti program ini maka setiap mahasiswa akan mendapatkan sertifikat sebagai persyaratan untuk mendaftar Ujian Skripsi dan sekaligus sebagai sertifikat pendamping ijazah sarjana S1 (strata satu) dari Fakultas Agama Islam (FAI) UIR.

Sementara populasi menurut Sutrisno Hadi adalah sekumpulan dari individu yang berhubungan dengan objek, baik berupa manusia maupun nilai-nilai atau peristiwa-peristiwa (Hadi 1999, hal. 36). Dari pengertian tersebut, yang menjadi populasi dalam penelitian ini adalah beberapa mahasiswa di setiap empat prodi FAI UIR sejumlah 394 orang.

Tabel 1.Rekapitulasi Data Mahasiswa FAI Peserta Program CELAD

\begin{tabular}{llccc}
\hline \multirow{2}{*}{ No } & \multirow{2}{*}{ Nama Prodi } & \multicolumn{2}{c}{ Jumlah Mahasiswa } & \multirow{2}{*}{ Total } \\
\cline { 3 - 4 } & & L & P & \\
\hline 1 & Pendidikan Agama Islam & 117 & 145 & 262 \\
\hline 2 & Ekonomi Syariah & 27 & 43 & 70 \\
\hline 3 & Perbankan Syari'ah & 16 & 25 & 41 \\
\hline 4 & Pendidikan Anak Usia Dini (PIAUD) & 3 & 18 & 21 \\
\hline & Total & & & $\mathbf{3 9 4}$ \\
\hline
\end{tabular}

Adapun sampel seperti yang diketahui adalah sebagian unit-unit observasi yang merupakan bagian dari populasi yang dianggap sebagai anggota populasi yang mewakili populasi secara keseluruhan (Sugiyono 2008, hal. 118). Dalam menentukan jumlah sampel, peneliti menggunakan teknik sampel bertujuan atau puposive sample. Sampel bertujuan dilakukan dengan cara mengambil subjek bukan didasarkan atas strata, random, atau daerah tetapi didasarkan atas adanya tujuan tertentu. Teknik ini biasanya dilakukan karena beberapa pertimbangan, misalnya alasan keterbatasan waktu, tenaga, dan biaya sehingga tidak dapat mengambil sampel yang besar dan jauh. Walaupun cara ini diperbolehkan, namun ada beberapa syarat yaitu: (1) pengambilan sampel harus didasarkan atas ciri-ciri, sifat- sifat atau karakteristik tertentu, yang merupakan ciri-ciri pokok populasi, (2) subyek yang diambil sebagai sampel benar-benar merupakan subjek yang paling banyak mengandung ciri-ciri yang terdapat pada populasi (key subjectif), dan (3) penentuan karakteristik populasi dilakukan dengan cermat di dalam 
studi pendahuluan (Arikunto: 2006, hal. 139-140).

Dengan pertimbangan tersebut, maka penelitian ini mengambil sampel sebesar 141 orang mahasiswa.

\section{Subjek dan Objek Penelitian}

Subjek penelitian ini adalah mahasiswa baru FAI UIR tahun ajaran 2018 pada semester satu. Sedangkan objek penelitian ini adalah penguasaan mufradat mahasiswa FAI UIR Pekanbaru.

\section{Sumber Data dan Teknik Pengumpulan Data}

Sumber yang digunakan dalam penelitian ini adalah: (a) Data primer yaitu data yang diperoleh melalui penelitian langsung kelokasi atau responden. Dalam penelitian ini dilakukan dengan cara meminta kepada mahasiswa baru FAI UIRuntuk mengisi angket; dan (b) Data sekunder yaitu data yang diperoleh dari bacaan literatur yang berkaitan dengan masalah yang diteliti dan hasil placement test bahasa Arab.

Untuk melengkapi data yang diperlukan dalam penelitian ini metode pengumpulan data yang digunakan adalah: (a) Angket atau kuesioner yaitu daftar pertanyaan/pernyataan yang diberikan kepada mahasiswabaru FAI UIR yang bersedia memberikan respon sesuai dengan permintaan pengguna, pengukuran variabel dilakukan dengan menggunakan skala lima alternatif pilihan (Skala Likert). Setiap variabel diberikan skor penilaian sebagai berikut: (1) (SS) Sangat Setuju= Skor 5; (2) (S) Setuju= Skor 4; (3) (N) Netral= Skor 3; (4) (TS) TidakSetuju= Skor 2; dan (5) (STS) SangatTidak Setuju= Skor 1 . (b) Dokumentasi yaitu penulisan akan menyimpulkan dari bahan-bahan dokumentasi yang berhubungan dengan masalah yang diteliti dan hasil placement test bahasa Arab yang dilakukan oleh CELAD dan placement test yang dilakukan oleh peneliti.

\section{Teknik Pengolahan dan Analisis Data}

Mengingat pengumpulan data melalui kuisioner, maka faktor kesungguhan responden dalam menjawab pertanyaan merupakan hal yang penting. Oleh karena itu tidak tertutup kemungkinan ada pertanyaan yang dijawab responden secara sungguh-sungguh. Untuk memastikan kesungguhan dan kepercayaan terhadap data yang telah dikumpulkan tersebut maka masih perlu dilakukan pengujian. Pengujian yang dilakukan adalah uji validitas dan reabilitas.

Peneliti menggunakan validasi internal. Validitas internal dapat dicapai apabila terdapat kesesuaian antara bagian-bagian instrumen secara keseluruhan (Arikunto 2006, hal. 171). Dan analisis validitas soal dapat dilakukan dengan menggunakan validitas butir soal. Adapun validitas butir bertujuan untuk menguji hubungan butir dengan skor total soal agar tidak menyimpang dari fungsi instrument. Prosedur untuk menganalisis butir soal, maka skorskor yang ada pada butir soal dikorelasikan dengan skor total. Skor butir dipandang sebagai nilai $\mathrm{X}$ dan skor total dipandang sebagai nilai $Y$ sehingga ditentukan korelasi dua bagian tersebut.

Selanjutnya, peneliti menggunakan reabilitas soal internal. Reabilitas internal diperoleh dengan cara menganalisis data dari satu kali hasil pengetesan. Untuk mengukur validitas 
dan reabilitas soal tersebut, maka peneliti menggunakan korelasi antar skor item instrument.

Dengan kata lain sebuah instrumen memiliki validitas internal dan reabilitas internal. Dan angket dalam penelitian ini merupakan cara pengumpulan data yang berkaitan dengan kelas bahasa Arab dan penguasaan mufradat bahasa Arab mahasiswa Fakultas Agama Islam UIR, dengan mengedarkan sejumlah daftar pertanyaan terhadap responden secara tertulis guna mendapatkan data yang sesuai dengan maksud dan tujuan penelitian. Dan untuk menguji hal tersebut, peneliti menggunakan program SPSS versi 23.

\section{Teknik Analisis data}

Dalam penelitian ini penulis menggunakan analisa data deskriptif caranya adalah apabila semua data telah terkumpul lalu diklasifikasikan menjadi dua kelompok yaitu: (a) Data kualitatif adalah metode penelitian yang digunakan untuk meneliti kondisi objek yang alamiah, (sebagai lawannya adalah eksperimen) yaitu penelitian adalah sebagai instrumen kunci, teknik pengumpulan data dilakukan secara triangulasi (gabungan), analisis data bersifat induktif dan hasil penelitian kualitatif lebih menekankan makna dari pada generalisasi; dan (b) Data kuantitatif adalah penelitian yang menggunakan angka dalam menyajikan data dan analisis yang menggunakan uji statistika. Penelitian kuantitatif merupakan penelitian yang dipandu oleh hipotesis tertentu, yang salah satu tujuan dari penelitian yang dilakukan adalah menguji hipotesis yang ditentukan sebelumnya (Beni Ahmad Saebani, 2008:121).

Data yang digunakan adalah data kuantitatif yaitu data yang berupa angka-angka dan analisis menggunakan statistik yang diambil dari hasil pengamatan mengenai situasi atau kejadian di lapangan (Sugiyono 2012, hal. 7). Adapun jenis data yang digunakan dalam penelitian ini meliputi pengaruh kelas bahasa Arab. Sedangkan data kuantitatif adalah penguasaan mufradat bahasa Arab.

Sumber data yang ada dalam penelitian ini terdiri dari 2 jenis yaitu sumber data primer dan sumber data sekunder. Data primer yaitu data yang diperoleh langsung dari tangan pertama, melalui prosedur dan teknik pengambilan data yang dapat berupa angket, maupun penggunaan instrumen pengukuran yang khusus dirancang sesuai dengan tujuan penelitian seperti placement test. Berdasarkan penjelasan tersebut, sumber data dalam penelitian ini adalah mahasiswa FAI UIR. Sedangkan data sekunder adalah data penunjang yang bersumber dari artikel, buku, jurnal, serta makalah-makalah yang ada relevansinya dengan pengaruh kelas bahasa Arab terhadap pengusaan mufradat mahasiswa FAI UIR.

\section{HASIL \\ Gambaran Umum Lokasi Penelitian Sejarah singkat CELADFAI UIR}

Dalam mengantisipasi persaingan dan kerjasama global, maka sebuah Perguruan Tinggi memerlukan Sumber Daya Manusia (SDM) yang tangguh, sikap profesionalisme yang mapan sesuai dengan bidangnya, dan kemampuan berinteraksi dengan pihak lain melalui penggunaan bahasa. Hal itu akan terwujud apabila penguasaan bahasa sebagai alat komunikasi dan pendidikan di kalangan civitas akademika lebih ditingkatkan kualitasnya melalui suatu lembaga atau pusat bahasa yang dikelola secara 
professional dengan melibatkan tenaga terampil yang ada pada universitas terutama FAI UIR.

Sebagaimana diketahui bahwa untuk melanjutkan studi S2 di berbagai Perguruan Tinggi Negeri di Indonesia, seorang calon mahasiswa (baik yang berbeasiswa dan non-beasiswa) harus lulus Tes Potensi Akademik (TPA) dan Test of English as a Foreign Language (TOEFL) serta Test of Arabic as a Foreign Language (TOAFL). Begitu pula halnya dengan banyaknya tawaran beasiswa internasional yang hingga kini belum dapat diakomodir oleh Universitas Islam Riau terutama FAI disebabkan oleh kurangnya penguasaan bahasa asing khususnya bahasa Inggris dan Arab. Padahal penguasaan bahasa Inggris dan Arab merupakan skill yang sangat penting bagi kualitas SDM dan modal utama untuk melanjutkan studi dan memperoleh beasiswa serta mendapatkan peluang pekerjaan yang lebih luas.

Pengembangan kampus UIR ke depan tidak menutup kemungkinan akan mengadakan kerjasama luar negeri dengan Amerika dan Eropa serta Timur Tengah dengan beberapa instansi dan perguruan tinggi yang tentunya sangat memerlukan skill kebahasaan dalam berkomunikasi. Di samping itu, adanya standarisasi terjemahan abstrak skripsi, dan thesis yang ada di Universitas Islam Riau khususnya Fakultas Agama Islam.

Dari latar belakang di atas, maka keberadaan Centre For Languages and Academic Development atau CELAD (Pusat Pengembangan Bahasa dan Akademik) di FAI sangatlah dibutuhkan sebagai wadah pembelajaran, layanan kursus/daurah bagi civitas akademika dan masyarakat umum, layanan penerjemahan, dan pemberdayaan masyarakat melalui aktivitas kebahasaan. Berdasarkan harapan dan cita-cita para pimpinan FAI UIR dinyatakan bahwa pentingnya pengembangan kompetensi bahasa Inggris dan Arab secara akademik dan non-akademik. Dengan demikian, Centre For Languages and Academic Development atau CELAD (Pusat Pengembangan Bahasa dan Akademik) di FAI ini merupakan lembaga pendukung yang akan berkontribusi terhadap kualitas akademik dan nonakademik di Universitas Islam Riau terutama FAI sehingga patut diusulkan pendiriannya dan keberadaannya.

\section{Visi dan Misi CELAD}

Adapun Visi dari CELAD adalah: "Menjadi pusat pembelajaran bahasa dan literasi yang profesional bagi Universitas Islam Riau dan masyarakat umum"

Sedangkan Misi dari CELAD adalah: (a) Mengembangkan programprogramkebahasaan dalam mendukung Catur Dharma Perguruan Tinggi UIR; (b) Memberikan layanan kursus, daurah dan pelatihan bahasa asing untuk menunjang peningkatan kualitas civitas akademika (dosen, staf dan mahasiswa) dan masyarakat umum serta pelatihan peningkatan kualitas guru dan calon guru dwibahasa; (c) Memberikan layanan penerjemahan (translation) secara umum dan khususnya terjemahan abstrak dari skripsi/thesis di Universitas Islam Riau khususnya FAI; (d) Menjalin kerjasama dengan lembaga-lembaga kebahasaan yang lain demi terwujudnya akselerasi programprogram bahasa; dan (e) Berperan serta secara aktif dalam pemberdayaan masyarakat melalui aktivitas kebahasaan.

\section{Rancangan Kerja}


Secara garis besar, rancangan kegiatan dapat dideskripsikan sebagai

berikut:

Tabel 2. Rancangan Kegiatan Program CELAD FAI UIR

\begin{tabular}{|c|c|c|}
\hline No & Kebijakan Program & Jenis Kegiatan \\
\hline 1 & Pendidikan & $\begin{array}{l}\text { a) Mengupayakan Laboratorium Bahasa atau } \\
\text { melakukan kerjasama dengan Laboratorium lain. } \\
\text { b) Menyelenggarakan program bahasa Inggris dan } \\
\text { Arab bagi civitas akademika. } \\
\text { c) Melakukan kerjasama dengan para Kaprodi FAI } \\
\text { dalam rangka standarisasi abstrak. } \\
\text { d) Mengembangkan kerjasama kelembagaan untuk } \\
\text { meningkatkan mutu SDM, baik pada tingkat lokal, } \\
\text { nasional dan internasional. }\end{array}$ \\
\hline 2 & $\begin{array}{l}\text { Penelitian } \\
\text { dan Pengembangan }\end{array}$ & $\begin{array}{l}\text { a) Melayani masalah kebahasaan dan penelitian } \\
\text { tentang bahasa dan budaya. } \\
\text { b) Pengembangan multimedia pembelajaran bahasa. }\end{array}$ \\
\hline 3 & $\begin{array}{l}\text { Pengembangan } \\
\text { Usaha }\end{array}$ & $\begin{array}{l}\text { a) Menyelenggarakan Pelatihan TOEFL, TOAFL, TOIC } \\
\text { bagi civitas akademika yang akan melanjutkan } \\
\text { studi. } \\
\text { b) Menyelenggarakan kursus atau daurah bahasa } \\
\text { Inggris dan Arab bagi civitas akademika dan } \\
\text { masyarakat umum } \\
\text { c) Melayani penerjemahan abstrak dari skripsi, dan } \\
\text { thesis. }\end{array}$ \\
\hline 4 & $\begin{array}{l}\text { Peningkatan } \\
\text { Citra FAI UIR }\end{array}$ & $\begin{array}{l}\text { Menyelenggarakan Seminar } \text { Nasional } \text { dan } \\
\text { Internasional Kebahasaan ataupun pendidikan bahasa } \\
\text { baik itu bekerjasama dengan Prodi PBA FAI UIR } \\
\text { maupun dengan lembaga bahasa lainnya. }\end{array}$ \\
\hline
\end{tabular}

\section{Deskripsi Data}

\section{Identitas Responden}

Dalam melakukan penelitian ini penulis telah mengumpulkan angket penelitian yang telah disebarkan kepada141mahasiswa FAI UIR Pekanbaru yang telah terkumpul dan memakai sampel random/ acak. Dalam penyajiannya penulis akan menyajikan seluruh identitas responden tersebut dalam bentuk tabulasi untuk lebih memudahkan pembaca dalam memahami tulisan.

Tabel 3. Data Jenis Kelamin Responden

\begin{tabular}{cccc}
\hline No & Jenis Kelamin & Frekuensi & Persentase \\
\hline $\mathbf{1}$ & Laki-laki & 31 & 22 \\
\hline $\mathbf{2}$ & Perempuan & 110 & 78 \\
\hline & Jumlah & $\mathbf{1 4 1}$ & $\mathbf{1 0 0}$ \\
\hline
\end{tabular}

Sumber: Data Olahan Angket, Identitas Responden 2018

Dari tabel di atas dapat respondenmahasiswa FAI UIR

diketahui bahwa jumlah Pekanbaru berdasarkan jenis kelamin 
laki-laki dan perempuan berjumlah 141 responden (100\%).

Tabel 4. Data Umur Responden

\begin{tabular}{cccc}
\hline No & Tingkat Umur & Frekuensi & Persentase \\
\hline 1 & $<20$ tahun & 141 & 100 \\
\hline & Jumlah & $\mathbf{1 4 1}$ & $\mathbf{1 0 0}$ \\
\hline
\end{tabular}

Sumber: Data Olahan Angket, Identitas Responden 2018

Dari tabel di atas dapat dilihat bahwa jumlah responden yang berusia $<20$ tahun berjumlah 141 (100\%). Jumlah responden keseluruhan berdasarkan tingkat umur menurut statistik adalah resoponden yang berusia <20 tahun berkisar antara umur 18-20 tahun dengan jumlah responden 141 orang (100\%) dari seluruh sampel.

Tabel 5. Data Prodi Responden

\begin{tabular}{cccc}
\hline No & Prodi & Frekuensi & Persentase \\
\hline 1 & PAI & 55 & 39 \\
\hline 2 & EKISY & 34 & 24 \\
\hline 3 & PIAUD & 15 & 10 \\
\hline 4 & PBS & 37 & 27 \\
\hline & Jumlah & $\mathbf{1 4 1}$ & $\mathbf{1 0 0}$ \\
\hline
\end{tabular}

Sumber : Data Olahan Angket, Identitas Responden 2018

Dari tabel di atas dapat dilihat bahwa jumlah respondenmahasiswa FAI UIR Pekanbaru. Prodi PAI jumlah responden sebanyak 55 (39\%), Prodi Ekisy, jumlah responden sebanyak 34 (24\%), Prodi PIAUD, jumlah responden sebanyak 15 (10\%), Prodi PBS, jumlah responden sebanyak 37 (27\%).

\section{Pengaruh Kelas Bahasa Arab (CELAD) terhadap Penguasaan Mufradat Mahasiswa FAI UIR.}

Hasil penelitian mengenai Pengaruh Kelas Bahasa Arab (CELAD) terhadap Penguasaan Mufradat Mahasiswa FAI UIR Pekanbaru.Berikut ini dijelaskan berdasarkan tanggapan responden tentang Pengaruh Kelas Bahasa Arab (CELAD) terhadap Penguasaan Mufradat Mahasiswa FAI UIRPekanbaru.

Berikut gambaran frekuensi dan presentase placement test yang dilakukan:

Tabel 6.Hasil Placement Test Bahasa Arab Pertama Sebelum Mengikuti Kelas Bahasa Arab (CELAD)

\begin{tabular}{clccc}
\hline No. & & Penilaian/ Skor & Frekuensi & Persentase \\
\hline 1 & Baik & 3 & 2,5 \\
\hline 2 & Cukup Baik & 2 & 1,5 \\
\hline 3 & Kurang Baik & 30 & 21 \\
\hline 4 & Sangat Kurang Baik & 105 & 74 \\
\hline 5 & False & 1 & 1 \\
\hline & Jumlah & $\mathbf{1 4 1}$ & $\mathbf{1 0 0}$ \\
\hline
\end{tabular}


Sumber : Data Olahan Angket No. 1, 2018

Berdasarkan tabel 7 di atas, dapat dilihat dari tanggapan responden di Kelas Bahasa Arab CELAD FAI UIR Pekanbaru tentangHasil Placement Test Bahasa Arab Pertama, responden yang memperoleh skor Baik 3 orang atau sebesar $2,5 \%$ sementara responden yang memperoleh skor Cukup Baik 2 orang atau sebesar 1,5\% sementara responden yang memperoleh skor Kurang Baik 30 orang atau sebesar $21 \%$ sementara responden yang memperoleh skor Sangat Kurang Baik105 orang atau sebesar $74 \%$ sementara responden yang memperoleh false 1 orang atau sebesar $1 \%$.

Tabel 7.Hasil Placement Test Bahasa Arab Kedua Sesudah Mengikuti Kelas Bahasa Arab (CELAD)

\begin{tabular}{clcc}
\hline No. & \multicolumn{1}{c}{ Penilaian/ Skor } & Frekuensi & Persentase \\
\hline 1 & Sangat Baik & 10 & 7 \\
\hline 2 & Baik & 16 & 11 \\
\hline 3 & Cukup Baik & 16 & 11 \\
\hline 4 & Kurang Baik & 25 & 18 \\
\hline 5 & Sangat Kurang Baik & 74 & 53 \\
\hline & Jumlah & $\mathbf{1 4 1}$ & $\mathbf{1 0 0}$ \\
\hline
\end{tabular}

Sumber : Data Olahan Angket No. 2, 2018

Berdasarkan tabel 8 di atas, dapat dilihat dari tanggapan responden tentangHasil Placement Test Kedua, responden yang memperoleh skor Sangat Baik10 orang atau sebesar 7\% sementara responden yang memperoleh skorBaik 16 orang atau sebesar $11 \%$ sementara responden yang memperoleh skor Cukup Baiksebanyak 16 orang atau sebesar $11 \%$ sementara responden yang memperoleh skorKurang Baik25 orang atau 18\% sementara responden yang memperoleh skor Sangat Kurang Baik sebanyak 74 orang atau 53\%, dan responden yang memperoleh skor False tidak ada.

\section{Berikut}

tanggapan

respondenPengaruh Kelas Bahasa Arab terhadap Penguasaan Mufradat
Mahasiswa FAI UIRberdasarkan perhitungan SPSSberikut ini :

Dalam pengolahan data ini, terdapat 118 responden yang dijadikan objek penelitian. Beberapa responden tidak dapat digunakan karena data yang tidak lengkap sehingga pada mulanya berjumlah 141 responden maka menjadi 118 responden yang valid.

Sebelum dilakukan uji $\mathrm{T}$ berpasangan, perlu dicek apakah data terdistribusi normal/tidak dengan melihat nilai Skewness dan Kurtosis sebagai asumsi yang harus dipenuhi. Bila nilai Skewness kurang dari 3 (nilai mutlak) dan Kurtosis kurang dari 10 (nilai mutlak), maka data dianggap masih terdistribusi dengan normal. 


\section{Tabel 8. Distribusi data}

\begin{tabular}{|c|c|c|c|c|c|c|c|c|c|}
\hline & & Minim & Maxi & & $\begin{array}{c}\text { Std. } \\
\text { Deviatio }\end{array}$ & & & & \\
\hline & $\mathrm{N}$ & um & mum & Mean & $\mathrm{n}$ & Ske & vness & Kur & tosis \\
\hline & $\begin{array}{l}\text { Stati } \\
\text { stic }\end{array}$ & $\begin{array}{l}\text { Statist } \\
\text { ic }\end{array}$ & $\begin{array}{c}\text { Statis } \\
\text { tic }\end{array}$ & $\begin{array}{l}\text { Statis } \\
\text { tic }\end{array}$ & Statistic & $\begin{array}{l}\text { Statis } \\
\text { tic }\end{array}$ & $\begin{array}{l}\text { Std. } \\
\text { Error }\end{array}$ & Statistic & Std. Error \\
\hline A1 & 118 & 1 & 5 & 3.86 & .626 & -.747 & .223 & 2.989 & .442 \\
\hline A2 & 118 & 1 & 5 & 4.42 & .733 & 2.052 & .223 & 7.093 & .442 \\
\hline A3 & 118 & 0 & 5 & 3.18 & .883 & -.207 & .223 & 1.080 & .442 \\
\hline B1 & 118 & 1 & 5 & 3.87 & 1.009 & $\begin{array}{r}- \\
1.366\end{array}$ & .223 & 1.744 & .442 \\
\hline B2 & 118 & 0 & 5 & 3.61 & 1.177 & $\begin{array}{r}- \\
1.053\end{array}$ & .223 & .455 & .442 \\
\hline B3 & 118 & 1 & 5 & 2.66 & .879 & .186 & .223 & .171 & .442 \\
\hline $\mathrm{C} 1$ & 118 & 0 & 5 & 3.46 & .912 & -.423 & .223 & .696 & .442 \\
\hline $\mathrm{C} 2$ & 118 & 2 & 5 & 3.75 & .703 & -.214 & .223 & -.020 & .442 \\
\hline $\mathrm{C} 3$ & 118 & 0 & 5 & 3.69 & .792 & -.950 & .223 & 3.149 & .442 \\
\hline $\mathrm{C} 4$ & 118 & 1 & 5 & 3.34 & .776 & -.339 & .223 & .461 & .442 \\
\hline D1 & 118 & 1 & 3 & 1.59 & .670 & .694 & .223 & -.588 & .442 \\
\hline D2 & 118 & 1 & 5 & 2.10 & .937 & .618 & .223 & .160 & .442 \\
\hline D3 & 118 & 1 & 5 & 2.69 & .947 & .404 & .223 & .501 & .442 \\
\hline D4 & 118 & 1 & 5 & 3.26 & .871 & -.462 & .223 & .487 & .442 \\
\hline D5 & 118 & 0 & 5 & 2.77 & 1.025 & -.204 & .223 & -.181 & .442 \\
\hline D6 & 118 & 0 & 5 & 2.79 & 1.053 & -.189 & .223 & -.397 & .442 \\
\hline D7 & 118 & 0 & 5 & 3.03 & 1.387 & -.242 & .223 & -1.171 & .442 \\
\hline D8 & 118 & 1 & 5 & 2.53 & 1.388 & .434 & .223 & -1.210 & .442 \\
\hline P1 & 118 & 30 & 90 & 50.14 & 14.274 & .452 & .223 & -.198 & .442 \\
\hline $\mathrm{P} 2$ & 118 & 10 & 96 & 57.43 & 20.740 & -.108 & .223 & -.675 & .442 \\
\hline $\begin{array}{l}\text { Valid N } \\
\text { (listwise }\end{array}$ & 118 & & & & & & & & \\
\hline
\end{tabular}

Berdasarkan Tabel di atas, dapat dikatakan bahwa data telah terdistribusi normal.

Selanjutnya, dilakukan uji $t$ berpasangan untuk melihat apakah ada perbedaan/peningkatan pengetahuan bahasa Arab yang signifikan sebelum dan setelah kegiatan belajar mengajar bahasa Arab. Bila nilai Sig kurang dari 0.05, maka dapat dikatakan bahwa terdapat perubahan yang signifikan. 
Tabel 9. Paired Samples Test atau Tes Sampel Berpasangan

\begin{tabular}{|c|c|c|c|c|c|c|c|c|}
\hline & \multicolumn{5}{|c|}{ Paired Differences } & \multirow[b]{3}{*}{$\mathrm{t}$} & \multirow[b]{3}{*}{$\mathrm{df}$} & \multirow{3}{*}{$\begin{array}{l}\text { Sig. (2- } \\
\text { tailed) }\end{array}$} \\
\hline & \multirow[b]{2}{*}{ Mean } & \multirow{2}{*}{$\begin{array}{c}\text { Std. } \\
\text { Deviatio } \\
\mathrm{n}\end{array}$} & \multirow{2}{*}{$\begin{array}{l}\text { Std. } \\
\text { Error } \\
\text { Mean }\end{array}$} & \multicolumn{2}{|c|}{$\begin{array}{c}\text { 95\% Confidence } \\
\text { Interval of the } \\
\text { Difference } \\
\end{array}$} & & & \\
\hline & & & & Lower & Upper & & & \\
\hline $\begin{array}{ll}\text { Pai } & \text { P1 - } \\
\text { r } 1 & \text { P2 }\end{array}$ & $\begin{array}{r}- \\
7.288\end{array}$ & 24.515 & 2.257 & -11.758 & -2.819 & 3.229 & 117 & .002 \\
\hline
\end{tabular}

Berdasarkan Tabel output Paired Samples Test di atas, dapat diketahui bahwa kegiatan belajar dan mengajar bahasa Arab telah memberikan pengaruh yang berarti dalam peningkatan kemampuan berbahasa Arab mahasiswa.

Tabel 10. Uji Multikolinieritas Berdasarkan KoefisienCoefficients ${ }^{a}$

\begin{tabular}{|c|c|c|c|c|c|c|c|c|}
\hline \multirow{2}{*}{\multicolumn{2}{|c|}{ Model }} & $\begin{array}{r}\text { Unstand } \\
\text { Coeffi }\end{array}$ & $\begin{array}{l}\text { ardized } \\
\text { ients }\end{array}$ & $\begin{array}{c}\text { Standardiz } \\
\text { ed } \\
\text { Coefficient } \\
\text { s } \\
\end{array}$ & \multirow[b]{2}{*}{$\mathrm{t}$} & \multirow[b]{2}{*}{ Sig. } & \multicolumn{2}{|c|}{ Collinearity Statistics } \\
\hline & & $\mathrm{B}$ & $\begin{array}{l}\text { Std. } \\
\text { Error }\end{array}$ & Beta & & & Tolerance & VIF \\
\hline 1 & $\begin{array}{l}\text { (Const } \\
\text { ant) }\end{array}$ & 1.673 & .375 & & 4.465 & .000 & & \\
\hline & $\mathrm{A}$ & .491 & .091 & .465 & 5.425 & .000 & .747 & 1.339 \\
\hline & $\mathrm{B}$ & .097 & .071 & .113 & 1.370 & .173 & .805 & 1.242 \\
\hline & $\mathrm{D}$ & -.157 & .065 & -.189 & -2.415 & .017 & .899 & 1.113 \\
\hline
\end{tabular}

a. Dependent Variable: $\mathrm{C}$

Berdasar Tabel di atas, tidak terdapat masalah multikolinieritas karena nilai VIF kurang dari 5.

Selanjutnya, tampak bahwa variable $B$ (peningkatan kemampuan berbahasa Arab) dipengaruhi secara signifikan dan positif oleh variabel A (pendapat/persepsi tentang bahasa Arab). Hal ini menunjukkan bahwa semakin baik persepsi mahasiswa terhadap bahasa Arab, semakin tinggi pula peningkatan kemampuan berbahasa Arab mereka. Mengapa demikian? Hal ini saling berkaitan antara persepsi dengan motivasi belajar. Semakin termotivasi di dalam mempelajari suatu pelajaran maka semakin membuat dirinya untuk memahami dan meningkatkan penguasaan pelajaran tersebut. Seperti yang diungkapkan oleh S. Nasution di dalam (Choiriyah: 2013) bahwa di antara faktor pendorong keberhasilan pebelajar adalah kesungguhan.

Di sisi lain, variabel B (waktu belajar bahasa Arab) dianggap secara signifikan tidak berpengaruh terhadap peningkatan kemampuan berbahasa Arab mahasiswa. Mengapa demikian? Karena lamanya seseorang belum tentu menunjukkan mudawamahnya atau kontinyu seseorang tersebut di dalam melakukan peningkatan belajar bahasa Arab. Ada jeda atau waktu tertentu yang membuat seseorang terhenti dalam beberapa waktu yang 
membuatnya tidak melakukan peningkatan belajar bahasa Arab. Kemudian bisa melakukannya kembali setelah masa jeda yang menunjukkan terhentinya melakukan peningkatan belajar bahasa Arab. Karena yang menjadi landasan keberhasilan seseorang dalam belajar seperti yang dijelaskan oleh S Nasution dalam (Choiriyah: 2013) adalah alokasi waktu yang disediakan dalam pertemuan atau pembelajaran tersebut baik di kelas maupun di luar kelas.

\section{Analisis Data}

Penelitian ini menggunakan statistik deskriptif yaitu penyajian data dengan tabel, perhitungan rata-rata dan persentase.Dari data angket yang dikumpulkan dari responden, dibuat olah selanjutnya data ditransformasikan dari data kualitatif menjadi data kuantitatif dengan memberi skor pada angket.Kriteria jawaban dan skor digunakan untuk mentransformasikan dari data kualitatif dari setiap indikator yang digunakan dalam konsep operasional.

Berdasarkan analisis yang dibuat SPSS terdapat angket responden yang rusak sebanyak 23 angket. Semula sebanyak 141 angket kemudian yang dapat diambil dan dinyatakan valid sebanyak 118 angket. Hal ini menunjukkan ada responden yang tidak menjawab secara sungguhsunguh dan nyata.

\section{Pembahasan Hasil Temuan}

Dari hasil perhitungan di atas diketahui bahwaterdapat pengaruh kelas bahasa Arab(CELAD)terhadap penguasaan mufradat Mahasiswa FAI UIR adalah karena akumulasi jawaban responden berada padaKontinum Skor Valid dan melalui Uji T-Berpasangan serta Uji Multikolinieritas yang menunjukkan adanya pengaruh kelas bahasa Arab (CELAD)terhadap penguasaan mufradat mahasiswa FAI UIR. Maka dapat disimpulkan bahwa pengaruh kelas bahasa Arab (CELAD) terhadap penguasaan mufradat mahasiswa FAI UIR dapat dikatakan baik.

Berdasarkan hasil jawaban responden tentang aspek persepsi menunjukkan mahasiswa FAI UIR punya semangat dan motivasi belajar yang cukup baik.

Berdasarkan hasil jawaban placement test satu dan dua tentang aspek hasil penilaian terdapat perubahan yang signifikan. Hanya mahasiswa dari Prodi PIAUD dan PBS masih terkendala di dalam menguasai bahasa Arab tersebut.

Motivasi responden untuk meningkatkan penguasaan bahasa Arab yang dimilikinya cukup baik. Perlu penanaman pemahaman dan persepsi yang berterusan di dalam dunia ilmu pengetahuan apalagi hal itu adalah bahasa Arab yang berkaitan dengan Al-Qur'an dan Sunnah Nabawiyah Shahihah.

Dari segi aspek alokasi waktu. Perlu mudawamah atau kontinyu di dalam melakukan peningkatan pemahaman dan penguasaan bahasa Arab terlebih lagi mufradat atau kosakata bahasa Arab yang sebenarnya adalah modal untuk merangkai kalimat, membentuk kalimat, dan membina kalimat yang lebih benar dan tepat di dalam pemakaiannya ditinjau dari segi bahasa Arab itu sendiri.

\section{SIMPULAN}

Berdasarkan hasil penelitian
yang diungkapkan pada bab-bab
sebelumnya, maka dapat ditarik
kesimpulan dan saran yang dapat 
penulis kemukakan sebagai berikut: pertama, Berdasarkan dimensi "pengaruh kelas bahasa" dari deskripsi di atas menunjukkan peran kesungguhan dari persepsi yang dibangun dapat mempengaruhi penguasaan bahasa Arab.

Kedua, Berdasarkan dimensi "penguasaan bahasa Arab" dari deskripsi di atas menjelaskan bahwa penguasaan tersebut memang tumbuh dan berkembang bila pebelajar dalam hal ini mahasiswa FAI UIR bersungguhsungguh, mengalokasikan waktu belajar di dalam kelas maupun di luar kelas, materi yang sesuai, kemampuan pebelajar itu sendiri, dan kepribadian guru menjadi penentu keberhasilan belajar.

Dengan melihat hasil penelitian yang dilakukan, dapat diambil kesimpulan bahwa pengaruh kelas bahasa Arab (CELAD) terhadap penguasaan mufradat mahasiswa FAI UIR dapat dikatakan "baik" karena dapat dilihat data yang diperoleh dari 118 responden maka rata-rata skor penelitian, t-berpasangan, dan uji multikolinieritas terletak pada daerah setuju atau valid.

\section{DAFTAR PUSTAKA}

Abd al-'Alim Ibrahim. Tt. Al-Muwajjih al-Fanniy li Mudarrisi al-Lughah al'Arabiyah.Beirut: Daral-Ma'ariftt.

Alwasilah, A Chaedar. 2011. Metodologi Pembelajaran Bahasa Arab. Bandung: Remaja Rosdakarya. Arikunto, Suharsimi. 1999. Dasar-Dasar Evaluasi Pendidikan Edisi Revisi. Jakarta: Bumi Aksara.

Arikunto, Suharsimi. 2006. Prosedur Penelitian Suatu Pendekatan Praktik. Revisi VI. Jakarta: Rineka Cipta.
Abd al-'Alim Ibrahim. Al-Muwajjih alFanniy li Mudarrisi al-Lughah al'Arabiyah. Beirut: Daral-Ma"ariftt.

Arikunto, Suharsimi. 2006. Prosedur Penelitian Suatu Pendekatan Praktik. Jakarta: Rineka Cipta.

Choiriyah. 2013. Pengaruh Program Bahasa Arab Minggu Dalam Peningkatan Kemampuan Bahasa Arab Santri Pondok Pesantren Raudhatul Ulum (PPRU) Sakatiga Palembang. Palembang: IAIN Raden Patah.

Fayid, Abdul Hamid. 1981. Raid AlTarbiyah Al-Ammah fi Tadris Lughah Al-Arabiyah. Beirut: Dar Al-Kutub AlYunani.

Hadi, Amirul \& H. Haryono. 2005. Metodologi Penelitian Pendidikan. Setia Jaya Bandung.

Ivor, Davis K. 1991. The Management to f-Learning. Penerjemah Sudarsono Sudirjo Lili Rumpas dan Koyo Kertasuryata. Jakarta: Rajawali.

Moleong, Lexy J. 1998. Metodologi Penelitian Kualitatif. Bandung: Remaja Rosda Karya.

Nasution, S. 1988. Berbagai Pendekatan dalam Proses Belajar Mengajar. Jakarta: Bulan Bintang.

Riduan dan Sunarto. 2012. Pengantar Statistika Untuk Penelitian. Bandung: Alfabeta.

Sugiyono. 2008. Metode Penelitian Pendidikan: Pendekatan Kuantitatif, Kualitatif dan R\&D. Bandung: Alfabeta.

Sumardi, Muljanto. 1975. Pengajaran bahasa Asing Sebuah Tinjauan Dari Segi Metodologi. Jakarta: Bulan Bintang.

Taringan, Henry., Guntur. 1993. Dasardasar Kurikulum Bahasa. Bandung: Angkasa.

Yunus, Mahmud. 1977. Metodik Khusus Bahasa Arab. Jakarta: Hidakarya Agung. 
Yusuf, Tayyar dan Saiful Anwar. 1999. Metodologi Pengajaran Agama dan bahasa Arab. Jakarta: Angkasa. 